\title{
MOVEMENT COORDINATION: PECULIARITIES OF STRENGTH EFFORT ASSESSMENT IN GIRLS AGED 11-13
}

\author{
Ivashchenko O.V. ${ }^{1}$, Cieślicka Mirosława ${ }^{2}$, Nosko M.O. ${ }^{3}$, Shcherbyk D.V. ${ }^{4}$ \\ ${ }^{1,4}$ H.S. Skovoroda Kharkiv National Pedagogical University \\ ${ }^{2}$ Collegium Medicum: Bydgoszcz, kujawsko pomorskie \\ ${ }^{3}$ Taras Shevchenko National University of "Chernihiv Collegium"
}

Corresponding Author: Ivashchenko O.V., e-mail: olga@tmfv.com.ua

Accepted for Publication: December 20, 2018

Published: December 25, 2018

DOI:10.17309/tmfv.2018.4.03

\begin{abstract}
The purpose of the study is to determine the peculiarities of strength effort assessment in girls aged 11-13. Materials and methods. The study participants were girls aged $11(n=25), 12(n=27), 13(n=18)$. The children and their parents were fully informed about all the features of the study and agreed to participate in the experiment. The paper used methods of scientific literature analysis, testing, methods of mathematical statistics. To determine the peculiarities of strength effort assessment, the study used a t-test for paired observations and a t-test for independent samples.

Results. The girls aged 11-13 demonstrate the best assessment of effort reproduction at 2/3 of maximum strength. There is no statistically significant age-related dynamics in strength effort assessment in girls aged 11-13. The correlation between the effort reproductions at $1 / 3,1 / 2$ and $2 / 3$ of maximum strength is not statistically significant.

Conclusions. In the process of physical education of girls aged 11-13, special attention should be paid to the development of motor control ability as the component of coordination training of schoolchildren.

Keywords: movement coordination, strength effort, motor control, girls aged 11-13.
\end{abstract}

\section{Introduction}

The research papers by Khudolii and Marchenko (2007), Ivashchenko (2016) focused on the development of motor abilities in schoolchildren. The regularities of coordination abilities development were described in the papers by Farfel (2011), Ilin (2003), Liakh (2000). Movement coordination is one of the basic abilities that can be developed in school age (Balsevich, 2000; Serhiienko, Chekmarova \& Khadzhynov, 2012; Ivashchenko, 2016).

Researchers found that the level of coordination abilities development influences the effectiveness of teaching motor actions (Khudolii, 2008; Ivashchenko, Khudolii, Iermakov, Lochbaum, Cieślicka, Zukow, Nosko \& Yermakova, 2017).

The research findings obtained by Lopatiev, Ivashchenko, Khudolii, Pjanylo, Chernenko and Yermakova (2017), Ivashchenko, Khudolii, Iermakov and Prykhodko (2018) reveal the multifactorial structure of motor

(C) Ivashchenko O.V., Cieślicka Mirosława, Nosko M.O., Shcherbyk D.V. 2018. abilities development in schoolchildren. In the structure of movement coordination, motor control ability plays a key role (Ilin, 2003; Khudolii \& Ivashchenko, 2014; Ivashchenko, 2016). Muscular strength is the basis for demonstrating schoolchildren's motor abilities, and the ability to assess muscular effort is key to evaluating the spatial and temporal characteristics of movement (Serhiienko, Chekmarova \& Khadzhynov, 2012; Ivashchenko, 2016). Farfel (2011) paid particular attention to the peculiarities of evaluating the spatial, temporal and strength characteristics of movement.

The planning of coordination abilities development requires the availability of informative pedagogic control indicators (Krutsevych, Vorobiov \& Bezverkhnia, 2011; Bodnar \& Andres, 2016; Ivashchenko \& Kapkan, 2016) and knowledge of their development peculiarities (Liakh, 2000; Khudolii, 2008; Ivashchenko, 2016).

The analysis of scientific literature suggests the need for further research on the peculiarities of strength effort assessment.

The purpose of the study is to determine the peculiarities of strength effort assessment in girls aged 11-13. 


\section{Materials and methods}

Study participants. The study participants were girls aged $11(\mathrm{n}=25), 12(\mathrm{n}=27), 13(\mathrm{n}=18)$. The children and their parents were fully informed about all the features of the study and agreed to participate in the experiment.

Study organization. The paper used methods of scientific literature analysis, testing, methods of mathematical statistics.

Testing procedure. Strength effort assessment. Equipment: dynamometer, calculator. Testing: the right hand maximum strength was measured for each participant. After that, they were asked to perform the following effort that equals to:

$1 / 3$ of maximum strength;

$1 / 2$ of maximum strength;

$2 / 3$ of maximum strength.

The result in $\mathrm{kg}$ was recorded in the protocol. The error of the produced effort was calculated in percentage. To determine the maximum effort, the testees made two attempts. The best result was recorded. The dosed effort was performed once.

Statistical analysis. To determine the peculiarities of strength effort assessment, the study used a t-test for paired observations and a t-test for independent samples.

\section{Results}

Table 1 shows the results of the analysis of age-related dynamics of strength effort assessment in the girls aged 11-13. There is no statistically significant dynamics in strength effort assessment in the girls aged 11-13.

Tables 2-4 show the results of the comparison of error when assessing different efforts. The girls aged 11 demonstrate the best assessment of effort at $2 / 3$ of maximum strength. The worst one - the effort at $1 / 3$ of maximum strength ( $p=0.001)$. There is a statistically significant correlation between the assessments of efforts at $1 / 3$ and $2 / 3$ of maximum strength $(p=0.035)$.

The girls aged 12 demonstrate the best assessment of effort at $2 / 3$ of maximum strength, the worst one the effort at $1 / 3$ of maximum strength $(p=0.001)$. There is no statistically significant correlation between the assessments of different efforts $(p>0.05)$.

The girls aged 13 demonstrate the best assessment of effort at $2 / 3$ of maximum strength, the worst one the effort at $1 / 3$ of maximum strength $(p=0.001)$. There

Table 1. Results of the analysis of age-related dynamics of strength effort assessment in the girls aged 11-13.

\begin{tabular}{|c|c|c|c|c|c|c|}
\hline Test & Age & $\mathbf{N}$ & Mean & Std. Deviation & $\mathrm{T}$ & $\mathbf{p}$ \\
\hline \multirow{3}{*}{ Hand maximum strength } & 11 & 25 & 29.48 & 8.28 & .638 & .526 \\
\hline & 12 & 27 & 28.07 & 7.60 & $.571^{\star *}$ & .571 \\
\hline & 13 & 18 & 28.00 & 8.53 & $.031^{\star \star \star}$ & .976 \\
\hline \multirow{3}{*}{$\begin{array}{l}\text { Effort at } 1 / 3 \text { of hand maximum } \\
\text { strength, } \%\end{array}$} & 11 & 25 & 34.63 & 16.07 & .272 & .787 \\
\hline & 12 & 27 & 33.61 & 10.70 & $.887^{\star \star}$ & .380 \\
\hline & 13 & 18 & 30.44 & 14.12 & $.856^{\star * *}$ & .397 \\
\hline \multirow{3}{*}{$\begin{array}{l}\text { Effort at } 1 / 2 \text { of hand maximum } \\
\text { strength, } \%\end{array}$} & 11 & 25 & 21.19 & 8.39 & -.165 & .869 \\
\hline & 12 & 27 & 21.62 & 10.30 & $-.721^{\star *}$ & .475 \\
\hline & 13 & 18 & 23.44 & 12.06 & $-.540^{\star \star \star}$ & .592 \\
\hline \multirow{3}{*}{$\begin{array}{l}\text { Effort at } 2 / 3 \text { of hand maximum } \\
\text { strength, } \%\end{array}$} & 11 & 25 & 15.55 & 8.15 & .106 & .916 \\
\hline & 12 & 27 & 15.32 & 7.44 & $-.227^{\star *}$ & .821 \\
\hline & 13 & 18 & 16.19 & 10.49 & $-.328^{\star * *}$ & .745 \\
\hline
\end{tabular}

${ }^{\star} 11-12$ years; ${ }^{* *} 11-13$ years; ${ }^{* * *} 12-13$ years

Table 2. Results of the analysis of peculiarities of strength effort assessment in the girls aged $11(n=25)$

\begin{tabular}{|c|c|c|c|c|c|c|}
\hline & Test & Mean & $\begin{array}{l}\text { Std. Error } \\
\text { Mean }\end{array}$ & Difference & $\mathbf{T}$ & $\mathbf{p}$ \\
\hline \multirow{2}{*}{ Pair 1} & Effort at $1 / 3$ of hand maximum strength, $\%$ & 34.63 & 3.21 & \multirow{2}{*}{13.44} & \multirow{2}{*}{3.346} & \multirow{2}{*}{.003} \\
\hline & Effort at $1 / 2$ of hand maximum strength, $\%$ & 21.18 & 1.68 & & & \\
\hline \multirow{2}{*}{ Pair 2} & Effort at $1 / 3$ of hand maximum strength, $\%$ & 34.63 & 3.21 & \multirow{2}{*}{19.08} & \multirow{2}{*}{6.524} & \multirow{2}{*}{.000} \\
\hline & Effort at $2 / 3$ of hand maximum strength, $\%$ & 15.55 & 1.63 & & & \\
\hline \multirow{2}{*}{ Pair 3} & Effort at $1 / 2$ of hand maximum strength, $\%$ & 21.19 & 1.68 & \multirow{2}{*}{5.64} & \multirow{2}{*}{2.199} & \multirow{2}{*}{.038} \\
\hline & Effort at $2 / 3$ of hand maximum strength, $\%$ & 15.55 & 1.63 & & & \\
\hline
\end{tabular}


Table 3. Results of the analysis of peculiarities of strength effort assessment in the girls aged $12(n=27)$

\begin{tabular}{|c|c|c|c|c|c|c|}
\hline & Test & Mean & $\begin{array}{c}\text { Std. Error } \\
\text { Mean }\end{array}$ & Difference & $\mathbf{T}$ & $\mathbf{P}$ \\
\hline \multirow{2}{*}{ Pair 1} & Effort at $1 / 3$ of hand maximum strength, $\%$ & 33.61 & 2.06 & \multirow{2}{*}{11.98} & \multirow{2}{*}{4.088} & \multirow{2}{*}{.000} \\
\hline & Effort at $1 / 2$ of hand maximum strength, $\%$ & 21.62 & 1.98 & & & \\
\hline \multirow{2}{*}{ Pair 2} & Effort at $1 / 3$ of hand maximum strength, $\%$ & 33.61 & 2.06 & \multirow{2}{*}{18.28} & \multirow{2}{*}{6.738} & \multirow{2}{*}{.000} \\
\hline & Effort at $2 / 3$ of hand maximum strength, $\%$ & 15.32 & 1.43 & & & \\
\hline \multirow{2}{*}{ Pair 3} & Effort at $1 / 2$ of hand maximum strength, $\%$ & 21.62 & 1.98 & \multirow{2}{*}{6.30} & \multirow{2}{*}{2.812} & \multirow{2}{*}{.009} \\
\hline & Effort at $2 / 3$ of hand maximum strength, $\%$ & 15.32 & 1.43 & & & \\
\hline
\end{tabular}

Table 4. Results of the analysis of peculiarities of strength effort assessment in the girls aged $13(\mathrm{n}=18)$

\begin{tabular}{|c|c|c|c|c|c|c|}
\hline & Test & Mean & $\begin{array}{l}\text { Std. Error } \\
\text { Mean }\end{array}$ & Difference & $\mathrm{T}$ & $\mathbf{P}$ \\
\hline \multirow{2}{*}{ Pair 1} & Effort at $1 / 3$ of hand maximum strength, $\%$ & 30.44 & 3.33 & \multirow{2}{*}{7.00} & \multirow{2}{*}{1.738} & \multirow{2}{*}{.1} \\
\hline & Effort at $1 / 2$ of hand maximum strength, $\%$ & 23.44 & 2.84 & & & \\
\hline \multirow{2}{*}{ Pair 2} & Effort at $1 / 3$ of hand maximum strength, $\%$ & 30.44 & 3.33 & \multirow{2}{*}{14.24} & \multirow{2}{*}{4.087} & \multirow{2}{*}{.001} \\
\hline & Effort at $2 / 3$ of hand maximum strength, $\%$ & 16.19 & 2.47 & & & \\
\hline \multirow{2}{*}{ Pair 3} & Effort at $1 / 2$ of hand maximum strength, $\%$ & 23.44 & 2.84 & \multirow{2}{*}{7.24} & \multirow{2}{*}{2.100} & \multirow{2}{*}{.051} \\
\hline & Effort at $2 / 3$ of hand maximum strength, $\%$ & 16.19 & 2.47 & & & \\
\hline
\end{tabular}

is no statistically significant correlation between the assessments of different efforts $(p>0.05)$.

\section{Discussion}

The study assumed that schoolchildren had peculiarities in assessing efforts at $1 / 3,1 / 2$ and $2 / 3$ of maximum strength. The study has found that there are no age-related changes in muscular effort assessment in the girls aged 11-13. This indicates that this age period is not sensitive to the development of the ability to assess strength effort. These results supplement the data of Balsevich (2000), Ilin (2003), Liakh (2000) on the sensitive periods of movement coordination development in children and adolescents, and the data of Nosko (2002), Nosko and Arkhypov (2014), Khudolii and Ivashchenko (2014) on motor function development in children and adolescents.

The girls aged 11-13 demonstrate the best assessment of effort at $2 / 3$ of maximum strength. These results confirm the data obtained by Ivashchenko (2016), Liakh (2000) showing that children and adolescents best assess efforts at 2/3 of maximum strength.

These findings confirm the conclusion made by Farfel (2011) that the errors in the assessment of different modalities in motor control do not correlate with one another and require a special training for ages 11-13. The importance and practical significance of the results of research on kinesthetic sensitivity are highlighted in the papers by $\mathrm{Li}, \mathrm{Su}, \mathrm{Fu}$ and Pickett (2015), Brink and Jacobs (2011), Morash, Pensky, Alfaro, and McKerracher (2012).

\section{Conclusions}

Girls aged 11-13 demonstrate the best assessment of effort at 2/3 of maximum strength. There is no statistically significant age-related dynamics in strength effort assessment in girls aged 11-13.

In the process of physical education of girls aged $11-13$, special attention should be paid to the development of motor control ability, the correlation between the effort reproductions at $1 / 3,1 / 2$ and $2 / 3$ of maximum strength is not statistically significant.

\section{Conflict of interest}

The author declares no conflict of interests.

\section{References}

Khudolii, O. M., \& Marchenko, S. I. (2007). Modeliuvannia rozvytku shvydkisno-sylovykh zdibnostei u shkoliariv 2-4 klasiv zasobamy rukhlyvykh ihor. Pedahohika, psykholohiia ta medyko-biolohichni problemy fizychnoho vykhovannia i sportu: naukova monohrafia za red. prof. Yermakova S.S. Kharkiv: KhDADM (KhKhPI), (8), 139142. (in Ukrainian)

Ivashchenko, O.V. (2016). Modeliuvannia protsesu fizychnoho vykhovannia shkoliariv: Monohrafiia. Kharkiv: OVS. (in Ukrainian)

Farfel, V. S. (2011). Upravlenie dvizheniiami v sporte. $M$. : Sovetskii sport, 202. (in Russian)

Ilin, E. P. (2003). Psikhomotornaia organizatciia cheloveka : ucheb. dlia vuzov. SPb. : Piter, 384. (in Russian)

Liakh, V.I. (2000). Dvigatelnye sposobnosti shkolnikov: Osnovy teorii i metodiki razvitiia. M.: Terra-Sport, 192. (in Russian) 
Balsevich, V.K. (2000). Ontokineziologiia cheloveka. M. : Teoriia i praktika fizicheskoi kultury, 275. (in Russian)

Serhiienko, L.P., Chekmarova, N.H., \& Khadzhynov, V.A. (2012). Psykhomotoryka: kontrol ta otsinka rozvytku : [Navchalnyi posibnyk]. Kharkiv : OVS, 270. (in Ukrainian)

Khudolii, O.M. (2008). Zahalni osnovy teorii i metodyky fizychnoho vykhovannia: Navchalnyi posibnyk. Kharkiv: OVS. (in Ukrainian)

Ivashchenko, O., Khudolii, O., Iermakov, S., Lochbaum, M., Cieślicka, M., Zukow, W., Nosko, M., \& Yermakova, T. (2017). Methodological approaches to pedagogical control of the functional and motor fitness of the girls from 7-9 grades. Journal of Physical Education and Sport (JPES), 17(1), 254-261. https://doi.org/10.7752/jpes.2017.01038

Ivashchenko, O., Khudolii, O., Iermakov, S., \& Prykhodko, V. (2018). Coordinating abilities: recognition of a state of development of 11-13 years old boys. Pedagogics, Psychology, Medical-Biological Problems of Physical Training and Sports, 22(2), 86-91. https://doi.org/10.15561/18189172.2018.0204

Lopatiev, A., Ivashchenko, O., Khudolii, O., Pjanylo, Y., Chernenko, S., \& Yermakova, T. (2017). Systemic approach and mathematical modeling in physical education and sports. Journal of Physical Education and Sport (JPES), 17(1), 146-155.

https://doi.org/10.7752/jpes.2017.s1023

Krutsevych, T.Iu., Vorobiov, V. I., \& Bezverkhnia, H. V. (2011). Kontrol u fizychnomu vykhovanni ditei, pidlitkiv i molodi: navch. posib. K.: Olimp. l-ra, 224. (in Ukrainian)

Nosko, M. O. (2002). Problema udoskonalennia rukhovoi funktsii v protsesi navchannia. Pedahohika, psykholohiia ta medyko-biolohichni problemy fizychnoho vykhovannia i sportu: zb. nauk. pr. za red. S. S. Yermakova. Kh., (1), 19-31. (in Ukrainian)
Nosko, M. O., \& Arkhypov, O. A. (2014). Biomekhanichna kharakterystyka rukhovykh yakostei liudyny (teoretychnyi analiz) [Elektronnyi resurs]. Visnyk Chernihivskoho natsionalnoho pedahohichnoho universytetu. Ser. : Pedahohichni nauky. Fizychne vykhovannia ta sport, 118(1), 227-239. url: http://nbuv.gov.ua/UJRN/ VchdpuPN_2014_118(1)_52 (in Ukrainian)

Khudolii, O.M., \& Ivashchenko, O.V. (2014). Modeliuvannia protsesu navchannia ta rozvytku rukhovykh zdibnostei u ditei i pidlitkiv: Monohrafiia. Kharkiv: OVS, 320. (in Ukrainian)

Bodnar, I., \& Andres, A. (2016). Tests and standards for express-control of physical fitness and health of middle school age pupils. Pedagogics, Psychology, Medical-Biological Problems of Physical Training and Sports, 20(4), 11-16. https://doi.org/10.15561/18189172.2016.0402

Ivashchenko, O. V., \& Kapkan, O. O. (2016). Informative pedagogic control indicators of 14-15 years age girls' motor fitness. Pedagogics, psychology, medical-biological problems of physical training and sports, 20(6), 18-25. https://doi.org/10.15561/18189172.2016.0603

Li, K., Su, W., Fu, H., \& Pickett, K. A. (2015). Kinesthetic deficit in children with developmental coordination disorder. Research in Developmental Disabilities, 38, 125-133. https://doi.org/10.1016/j.ridd.2014.12.013

Brink, A. O., \& Jacobs, A. B. (2011). Kinesthetic Sensitivity and Related Measures of Hand Sensitivity in Children With Nonproficient Handwriting. Pediatric Physical Therapy, 23(1), 88-94. https://doi.org/10.1097/PEP.0b013e318208cc81

Morash, V., Pensky, A. E. C., Alfaro, A. U., \& McKerracher, A. (2012). A Review of Haptic Spatial Abilities in the Blind. Spatial Cognition and Computation, 12(2-3), 83-95. https://doi.org/10.1080/13875868.2011.599901

\title{
КООРДИНАЦІЯ РУХІВ: ОСОБЛИВОСТІ ОЦІНКИ СИЛОВИХ ЗУСИЛЬ У ДІВЧАТ 11-13 РОКІВ
}

\author{
Іващенко О.В. ${ }^{1}$, Цеслицька М. ${ }^{2}$, Носко M.O. ${ }^{3}$, Щербик Д.В. ${ }^{4}$ \\ ${ }_{1,4}$ Харківський національний педагогічний університет імені Г.С. Сковороди \\ ${ }^{2}$ Медичний колегіум: Бидгощ, Куявсько-Поморське воєводство \\ ${ }^{3}$ Національний університет «Чернігівський колегіум» імені Т.Г. Шевченка
}

Реферат. Стаття: 5 с., 4 табл., 20 джерел.

Мета дослідження - визначити особливості оцінки силових зусиль у дівчат 11-13 років. Матеріал і методи. У дослідженні прийняли участь дівчата 11 років $(\mathrm{n}=25), 12$ років $(\mathrm{n}=27), 13$ років $(\mathrm{n}=18)$. Діти та їхні батьки були інформовані про всі особливості дослідження і дали згоду на участь в експерименті. У роботі використані методи аналізу наукової літератури, тестування, методи математичної статистики. Для визначення особливостей оцінки силових зусиль був використаний t-тест для парних спостережень i t-тест для незалежних виборок.

Результати дослідження. Дівчата 11-13 років найкраще оцінюють відтворення зусилля $2 / 3$ від максимального. Статистично достовірної вікової динаміки в оцінці силових зусиль у дівчат 11-13 
років не спостерігається. Взаємозв'язок між відтворенням зусилля $1 / 3,1 / 2$ та $2 / 3$ від максимального статистично не достовірний.

Висновки. У процесі фізичного виховання дівчат 11-13 років необхідно акцентувати увагу на формування здібності до управління рухами як компоненти координаційної підготовки школярів.

Ключові слова: координація рухів, силові зусилля, управління рухами, дівчата 11-13 років.

\title{
КООРДИНАЦИЯ ДВИЖЕНИЙ: ОСОБЕННОСТИ ОЦЕНКИ СИЛОВЫХ УСИЛИЙ У ДЕВОЧЕК 11-13 ЛЕТ
}

\author{
Иващенко О.В. ${ }^{1}$, Цеслицька М. ${ }^{2}$, Носко Н.А. ${ }^{3}$, Щербик Д.В. ${ }^{4}$ \\ ${ }_{1,4}$ Харьковский национальный педагогический университет имени Г.С. Сковороды \\ ${ }^{2}$ Медицинский коллегиум: Быдгощ, Куявско-Поморское воеводство \\ ${ }^{3}$ Национальний университет «Черниговский коллегиум» имени Т.Г. Шевченко
}

Реферат. Статья: 5 с., 4 табл., 20 источников.

\begin{abstract}
Цель исследования - определить особенности оценки силовых усилий у девочек 11-13 лет.

Материал и методы. В исследовании приняли участие девочки 11 лет ( $\mathrm{n}=25), 12$ лет $(\mathrm{n}=27), 13$ лет $(\mathrm{n}=18)$. Дети и их родители были осведомлены обо всех особенностях исследования и дали согласие на участие в эксперименте. В работе использованы методы анализа научной литературы, тестирование, методы математической статистики. Для определения особенностей оценки силовых усилий был использован t-тест для парных наблюдений и t-тест для независимых выборок.
\end{abstract}

Результаты исследования. Девочки 11-13 лет лучше оценивают воспроизведение усилия $2 / 3$ от максимального. Статистически достоверной возрастной динамики в оценке силовых усилий у девочек 11-13 лет не наблюдается. Взаимосвязь между воспроизведением усилия $1 / 3,1 / 2$ и $2 / 3$ от максимального статистически не достоверна.

Выводы. В процессе физического воспитания девочек 11-13 лет необходимо акцентировать внимание на формирование способности к управлению движениями как компоненты координационной подготовки школьников.

Ключевые слова: координация движений, силовые усилия, управление движениями, девочки $11-13$ лет.

\section{Information about the authors:}

Ivashchenko O.V.: olga@tmfv.com.ua; https://orcid.org/0000-0002-2708-5636; Department of Theory and Methodology of Physical Education, Health and Medical Physical Culture, H. S. Skovoroda Kharkiv National Pedagogical University, Alchevskikh St, 29, Kharkiv, 61002, Ukraine.

Cieślicka M.: cudaki@op.pl; https://orcid.org/0000-0002-0407-2592; Collegium Medicum: Bydgoszcz, kujawsko pomorskie, Chodkiewicza St, 30, 85-064 Bydgoszcz, Poland.

Nosko M.O.: chnpu@chnpu.edu.ua; https://orcid.org/0000-0001-9903-9164; Department of Pedagogy, Psychology and Methodology of Physical Education, Taras Shevchenko National University of "Chernihiv Collegium", Hetman Polubotka St, 70, Chernihiv, Chernigov region, 14000, Ukraine.

Shcherbyk D.V.: Shcherbyk.D@gmail.com; https://orcid.org/0000-0002-2761-0410; Department of Theory and Methodology of Physical Education, Health and Medical Physical Culture, H. S. Skovoroda Kharkiv National Pedagogical University, Alchevskikh St, 29, Kharkiv, 61003, Ukraine.

Cite this article as: Ivashchenko, O.V., Cieślicka, M., Nosko, M.O., \& Shcherbyk, D.V. (2018). Movement Coordination: Peculiarities of Strength Effort Assessment in Girls Aged 11-13. Teoriâ ta Metodika Fìzičnogo Vihovannâ, 18(4), 175-179. https://doi.org/10.17309/tmfv.2018.4.03

Received: 10.11.2018. Accepted: 20.12.2018. Published: 25.12.2018 